\title{
Hepatocurative Effect of Saussurea lappa C.B Clarke and Artemisia absinthium, Linn in Chronic Hepatitis B
}

\author{
Shabnam Ansari ${ }^{*}$, Mohammad Akhtar Siddiqui ${ }^{2}$, Mohammad Maaz ${ }^{2}$ \\ 'Department of Biotechnology, Faculty of Natural Sciences, Jamia Millia Islamia, New Delhi, INDIA. \\ 2Department of Moalajat, School of Unani Medical Education and Research, Jamia Hamdard, New Delhi, INDIA.
}

\begin{abstract}
Objective: Repeated immune attacks in chronic hepatitis B produce recurrent inflammation in the liver and render it to develop fibrous tissue and carcinoma. Hence, present study aims to evaluate the hepatocurative effect of qust (Saussurea lappa) and afsanteen (Artemisia absinthium) in the chronic hepatitis B patients. Methods: In a single arm pilot clinical study, 30 patients of chronic hepatitis B with ALT (alanine aminotransferase) $>2$ times of upper limit of normal were treated with decoction of qust (Saussurea lappa) and decoction of afsanteen (Artemisia absinthium) daily orally for 3 months. Patients were evaluated for liver function test at baseline, $6^{\text {th }}$ week and $12^{\text {th }}$ week of treatment. Result: Test drug reduced the mean serum bilirubin, ALT, AST highly significantly at $12^{\text {th }}$ week of treatment. $(p<0.01)$. Conclusion We reviewed the literature related to the test drug, Saussurea lappa and Artemisia absinthium used for the treatment in these cases. The observed hepatocurative effect could be due anti-inflammatory, hepatoprtotective, antioxidant and immunomodulator properties of these drugs, substantiated in various animal studies.
\end{abstract}

These findings indicate the hepatocurative effect of Saussurea lappa and Artemisia absinthium in chronic hepatitis B cases. Randomized controlled clinical studies should be conducted to explore the further efficacy.

Key words: Saussurea lappa, Artemisia absinthium, Hepatocurative, Unani medicine, Liver tonic, Hepatitis.

Key message: To establish hepatocurative nature of decoction of Saussurea lappa and Artemisia absinthium in chronic hepatitis B patients with deranged liver function test.

Correspondence

Dr. Shabnam Ansari, Department of Biotechnology, Faculty of Natural Sciences, Jamia Millia Islamia, New Delhi, INDIA.

Phone: +919818168642

Email: drshabnamansari.md@gmail.com

DOI: 10.5530/jyp.2018.10.78

\section{INTRODUCTION}

Chronic Hepatitis B (CHB) is a chronic necro-inflammatory condition in the liver characterized by the presence of detectable hepatitis B surface antigen (HBsAg) in the blood or body fluids for longer than 6 months. ${ }^{1}$ Necro-inflammation of the liver cells occur as a result of immune attacks in response to hepatitis B virus. Persistent inflammation of the hepatic cells may lead to liver fibrosis and ultimately hepatocellular carcinoma. India has more than 40 million people infected with hepatitis B and every year 6 lakhs Indians die due to HBV-related end stage liver diseases. ${ }^{2-3}$

Unani system of medicine is one of the oldest traditional system of medicine which has been treating hepatitis efficiently with drugs of herbal origin since centuries. Water based decoctions of qust (Saussurea lappa) and afsanteen (Artemisia absinthium) has been documented to had highly beneficial therapeutic efficacy in resolution and normalization of abnormal liver conditions including hepatitis. ${ }^{4-5}$ Thus, present study was done to evaluate the hepatocurative effect of decoction of Saussurea lappa and Artemisia absinthium in chronic hepatitis B.

\section{MATERIAL AND METHODS}

\section{Ethical consideration}

This study was registered in the clinical trial registry of India, Govt. of India with registration no. CTRI/2017/11/010386. The purpose, procedure and potential risks of this study have been explained to each participant. The protocol was approved by the Institutional Ethics Committee of Jamia Hamdard (Hamdard University) and was implemented in accordance with provisions of the Declaration of Helsinki, ICMR and Good Clinical Practice (GCP) guidelines. Written informed consent was obtained from the patients before beginning of the study. (JH IEC/ 1530 HOURS/ AUGUST 12/ 15)

\section{Study subjects}

This was an open single arm prospective study of $30 \mathrm{HBeAg}$ positive and negative $\mathrm{CHB}$ patients who were recruited in inpatient and outpatient department of Majeedia Unani Hospital, Jamia Hamdard, New Delhi between August 2015 to June 2016. The inclusion criteria's were 1) clinically stable patients of both sexes in the age groups of 18 to 60 years 2) positive HBsAg for more than 6 months 5) HBV DNA quantitative greater than $2,000 \mathrm{IU} / \mathrm{mL}, 6$ ) ALT (alanine aminotransferase) $>2$ times of upper limit of normal and 7) both $\mathrm{HBeAg}$ positive and negative patients. The exclusion criteria's were 1) patient below 18 years 2) patient above 60 years 3 ) pregnant women and lactating mothers 4) mentally retarded person 5) patients who fail to give informed consent 6) patient with cirrhosis, portal hypertension/ ascites and obstructive jaundice, 7) patients of diabetes and hypertension, 8) patients with kidney and heart disease, and 9) patients with neurological disorder.

\section{Study treatment}

Identification: Roots of qust (Saussurea lappa) and plant of afsanteen (Artemisia absinthium) were purchased from the local market at Khari Baoli, Old Delhi, India. Voucher specimens were deposited in the Herbarium of Department of Botany, Faculty of Science, Jamia Hamdard, New Delhi, India and were identified and authenticated by Prof. (Dr.) M.P Sharma as qust (Saussurea lappa) and afsanteen (Artemisia absinthium) respectively. Physiochemical standardization of herbs was also done for quality control. 
Dose: Decoction of crude root of qust (Saussurea lappa), $15 \mathrm{ml}$ (containing approx. $1 \mathrm{~g}$ of dried extract), advised in the morning empty stomach daily, for 12 weeks. Decoction of crude whole plant of afsanteen (Artemisia absinthium), $15 \mathrm{ml}$ (containing approx. $1 \mathrm{~g}$ of dried extract), advised in the evening empty stomach daily for 12 weeks.

\section{Preparation of decoction}

Decoction of each herb was prepared in the similar manner. Saussurea lappa and Artemisia absinthium were purchased in bulk to prevent batch to batch variation in quality of herbs.

Decoction of both the drugs was prepared in the similar manner. Drug (root of Saussurea or plant of Artemisia), $7 \mathrm{~g}$ was dissolved in 16 times of $\mathrm{w} / \mathrm{v}$ (approx. $115 \mathrm{ml}$ of water in $500 \mathrm{ml}$ round bottom flask) and soaked for overnight. Thereafter, drug solution was allowed to be heated at $40^{\circ} \mathrm{C}$ for $5 \mathrm{~h}$ till it reduced to $1 / 4$ th of the original volume. Strained and filtered solution thus obtained (approx. $30 \mathrm{ml})$ was concentrated to its half $(15 \mathrm{ml})$ to give liquid extract containing $1 \mathrm{~g}$ of dried extract. A single dose of $15 \mathrm{ml}$ per day of decoction of each herb was established. Preservative was added. The decoction of both the drugs were stored at room temperature in the laboratory before use. High performance thin layer chromatography of decoction of both the drugs was also done for the purpose of quality control.

\section{Measurements}

Serum Bilirubin total, direct and indirect, serum glutamic oxaloacetic transaminase (SGOT/ AST), serum glutamic pyruvic transaminase (SGPT/ ALT), and alkaline phosphatase were measured at baseline, $45^{\text {th }}$ day (mid-treatment) and $90^{\text {th }}$ day (after treatment).

\section{Statistical analysis}

Normal-distributed continuous variables were given as mean \pm standard deviation (SD). Continuous variables were compared by Tukey-Kramer multiple comparisons test through GraphPad Prism, version 7.00 for windows created on March 31, 2016. Differences were considered significant when the $\mathrm{p}$ value was less than 0.05 . Test results were ranked as: ns - Non significant $p>0.05,{ }^{*} p<0.05$ significant, ${ }^{* *} p<0.01$ very significant, ${ }^{* * *} p<0.001$ extremely significant.

\section{RESULT}

\section{Effect of test drug on serum bilirubin}

Mean serum bilirubin (total) in total patients $(n=30)$ at baseline was $2.15 \pm \mathrm{SD} 2.33 \mathrm{mg} / \mathrm{dL}$ which reduced to $0.82 \pm \mathrm{SD} 0.47 \mathrm{mg} / \mathrm{dL}$ at $6^{\text {th }}$ week $(\mathrm{p}<0.01)$ and furthermore significantly reduced to $0.74 \pm \mathrm{SD} 0.29 \mathrm{mg} / \mathrm{dL}$ at $12^{\text {th }}$ week after treatment. $(\mathrm{p}<0.001)$ (Table 1 , Figure 1$)$

Mean serum bilirubin (direct) in total patients $(\mathrm{n}=30)$ at baseline was $1.27 \pm \mathrm{SD} 1.66 \mathrm{mg} / \mathrm{dL}$ which reduced to $0.35 \pm \mathrm{SD} 0.23 \mathrm{mg} / \mathrm{dL}$ at $6^{\text {th }}$ week $(\mathrm{p}<0.01)$ and furthermore significantly reduced to $0.31 \pm \mathrm{SD} 0.14 \mathrm{mg} / \mathrm{dL}$ at $12^{\text {th }}$ week after treatment. $(\mathrm{p}<0.001)$ (Table 1 , Figure 1$)$

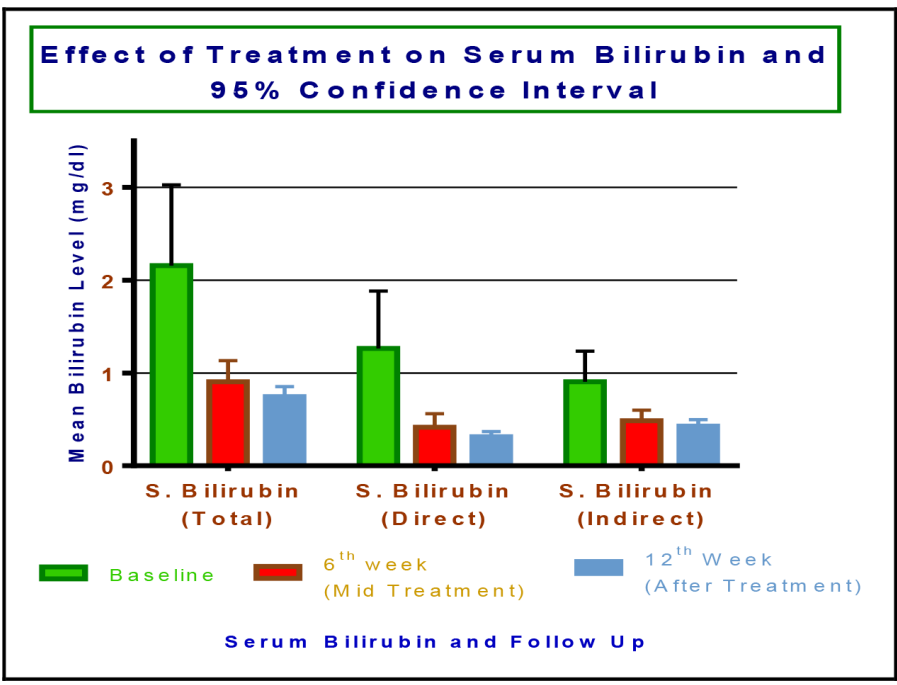

Figure 1: Effect of test drug on serum bilirubin.

Mean serum bilirubin (indirect) in total patients $(\mathrm{n}=30)$ at baseline was $0.90 \pm \mathrm{SD} 0.89 \mathrm{mg} / \mathrm{dL}$ which reduced to $0.46 \pm \mathrm{SD} 0.30 \mathrm{mg} / \mathrm{dL}$ at $6^{\text {th }}$ week $(\mathrm{p}<0.01)$ and furthermore significantly reduced to $0.43 \pm \mathrm{SD} 0.19 \mathrm{mg} / \mathrm{dL}$ at $12^{\text {th }}$ week after treatment. $(\mathrm{p}<0.001)$ Difference in mean values of serum bilirubin (total, direct and indirect) at mid vs. after treatment were non-significant . ( $>>0.05)$ (Table 1, Figure 1)

\section{Percentage of patients achieved normal serum bilirubin (total) levels after treatment}

Among 30 patients, 14 (46.66\%) patients had deranged serum bilirubin (total) at baseline which was normalized in $12(87.71 \%)$ patients after 12 weeks of treatment with test drug. $(\mathrm{p}<0.0001)$

\section{Effect of test drug on liver enzymes}

Mean ALT in total patients $(\mathrm{n}=30)$ at baseline was $272 \pm$ SD $463 \mathrm{IU} / \mathrm{mL}$ which significantly reduced to $69.28 \pm \mathrm{SD} 120 \mathrm{IU} / \mathrm{mL}$ at $6^{\text {th }}$ week $(\mathrm{p}<0.05)$ and furthermore significantly reduced to $42.1 \pm \mathrm{SD} 48 \mathrm{IU} / \mathrm{mL}$ at $12^{\text {th }}$ week after treatment. $(p<0.01)$ (Table 2, Figure 2)

Mean AST in total patients $(\mathrm{n}=30)$ at baseline was $221.7 \pm \mathrm{SD} 377 \mathrm{IU} / \mathrm{mL}$ which significantly reduced to $48.9 \pm \mathrm{SD} 50 \mathrm{IU} / \mathrm{mL}$ at $6^{\text {th }}$ week $(\mathrm{p}<0.01)$ and furthermore significantly reduced to $35 \pm \mathrm{SD} 26 \mathrm{IU} / \mathrm{mL}$ at $12^{\text {th }}$ week after treatment. $(p<0.01)$ (Table 2, Figure 2)

Difference in mean values of ALT and AST at mid vs. after treatment were non-significant. $(p>0.05)$

Mean alkaline phosphatase in total patients $(n=30)$ at baseline was $182 \pm \mathrm{SD} 133 \mathrm{IU} / \mathrm{mL}$ which non-significantly reduced to $138 \pm \mathrm{SD}$ $51 \mathrm{IU} / \mathrm{mL}$ at $6^{\text {th }}$ week $(p>0.05)$ and further non-significantly reduced to

Table 1: Effect of test drug on serum bilirubin $(\mathrm{mg} / \mathrm{dL})$.

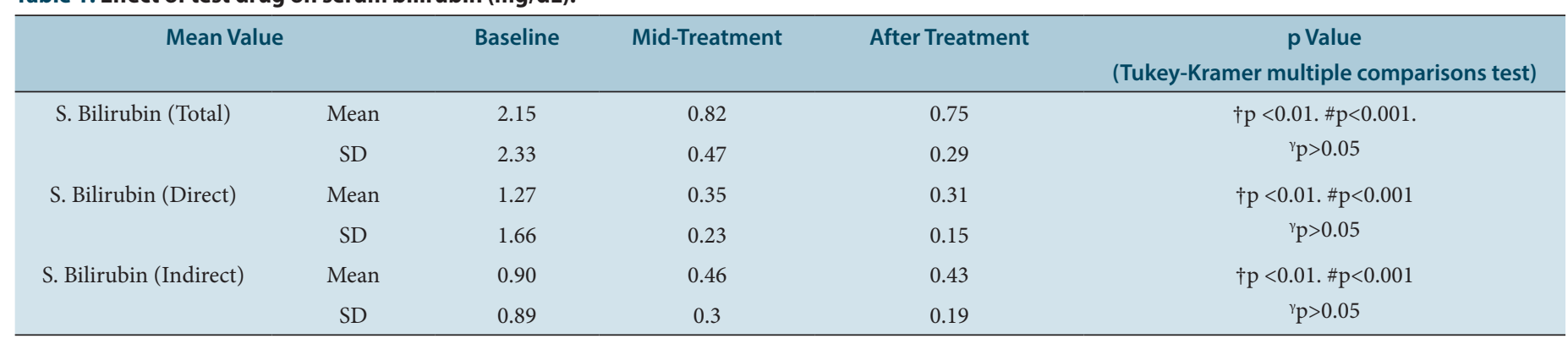

$\dagger$ Baseline Vs. Mid Treatment; \#Baseline Vs. After Treatment; $\gamma$ Mid Treatment Vs. After Treatment. 
Table 2: Effect of Test drug on Liver enzymes (IU/L).

\begin{tabular}{|c|c|c|c|c|c|c|}
\hline \multicolumn{2}{|c|}{ Mean Value } & \multirow{2}{*}{$\begin{array}{c}\text { Baseline } \\
221.7\end{array}$} & \multirow{2}{*}{$\begin{array}{c}\text { Mid-Treatment } \\
48.9\end{array}$} & \multirow{2}{*}{$\begin{array}{c}\text { After Treatment } \\
34.9\end{array}$} & \multirow{2}{*}{$\begin{array}{c}\text { Mean reduction\# } \\
186.8\end{array}$} & \multirow{2}{*}{$\begin{array}{c}\mathrm{p} \text { Value } \\
\begin{array}{c}\text { (Tukey-Kramer multiple } \\
\text { comparisons test) }\end{array} \\
\dagger \mathrm{p}<0.01\end{array}$} \\
\hline AST/ SGOT & Mean & & & & & \\
\hline & & & & & & $\# \mathrm{p}<0.01$ \\
\hline & SEM & 68.8 & 9.13 & 4.84 & & ${ }^{\gamma} \mathrm{p}>0.05$ \\
\hline \multirow[t]{3}{*}{ ALT/ SGPT } & Mean & 272.13 & 69.28 & 42.1 & 230.03 & $\dagger \mathrm{p}<0.05$ \\
\hline & & & & & & $\# \mathrm{p}<0.01$ \\
\hline & SEM & 84.59 & 22 & 8.7 & & ${ }^{\gamma} \mathrm{p}>0.05$ \\
\hline \multirow[t]{3}{*}{ Alkaline Phosphatase } & Mean & 182.5 & 138.3 & 137.3 & 45.2 & $\dagger p>0.05$ \\
\hline & & & & & & $\# p>0.05$ \\
\hline & SEM & 24.4 & 9.3 & 8.1 & & ${ }^{\gamma} \mathrm{p}>0.05$ \\
\hline
\end{tabular}

$\dagger$ †aseline Vs. Mid Treatment; \#Baseline Vs. After Treatment; $\gamma$ Mid Treatment Vs. After Treatment.

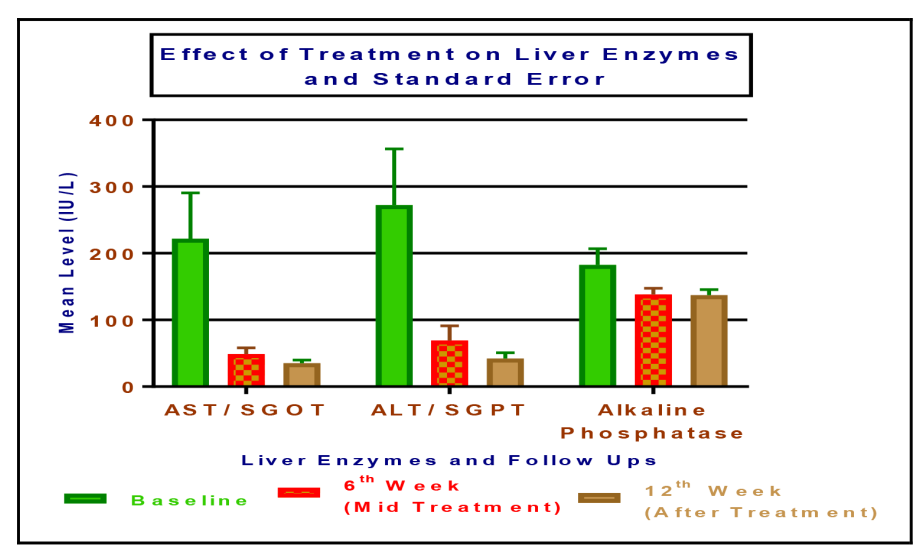

Figure 2: Effect of test drug on liver enzymes.

$137 \pm \mathrm{SD} 44 \mathrm{IU} / \mathrm{mL}$ at $12^{\text {th }}$ week after treatment. $(\mathrm{p}>0.05)$ Mean alkaline phosphatase was within normal limit at baseline. (Table 2, Figure 2)

\section{DISCUSSION}

Bae et al. (2010) have reported mean reduction of ALT from baseline at $12^{\text {th }}$ week was $-86.2 \pm 227.2,-73.2 \pm 118.6$ and $-128.1 \pm 170.4 \mathrm{IU} / \mathrm{mL}$ in lamivudine $(n=68)$, clevudine $(n=39)$ and entecavir $(n=39)$ treated patients respectively which was non-significant at $\mathrm{p}>0.05 .{ }^{6}$ In our study, mean reduction at $12^{\text {th }}$ week was $-230 \pm \mathrm{SD} 415 \mathrm{IU} / \mathrm{mL}(\mathrm{n}=30)$ which was highly significant at $\mathrm{p}<0.01$ which may substantiate potent efficacy of Unani test drug in resolution of liver inflammation. Significant reduction in abnormal liver profile in our study patients has validated hepatocurative potential of Saussurea lappa and Artemisia absinthium in chronic hepatitis $B$. The plausible mechanism of such effect could be attributed to the hepatoprotective, anti-inflammatory, immunomodulatory and anti-oxidant properties of Saussurea lappa $a^{7-15}$ and Artemisia absinthium ${ }^{16-22}$ have been reported in various studies. These drugs have either prevented the further rise of liver enzymes or resolved the inflammation of the liver through their mitigating effect by targeting inflammatory cascade or attenuating or scavenging effect on generation of ROS species. In chronic $\mathrm{HBV}$ infection, repeated immune attacks through T cells triggers production of inflammatory cytokines including IFN- $\gamma$, TNF- $\alpha$, interleukin (IL) 2 etc. which produced inflammatory hepatic flares. ${ }^{23}$ Amat et al.
(2010), reported that aqueous extract of Artemisia absinthium modulated TNF and IL activity in LPS induced mice model. ${ }^{16}$ Similarly, Pandey et al. (2012) have also reported the immunomodulatory action of Saussurea lappa through which inflammatory cascade could be modulated viz. inflammation of the liver. ${ }^{24}$ In addition, Saussurea lappa and Artemisia absinthium are one of the important drugs in liver diseases. Both of them have been used as liver tonic (muqawwiye jigar) since long time in the treatment of hepatitis, jaundice and others diseases of the liver. ${ }^{4-5}$

\section{CONCLUSION}

These observations substantiate the hepatocurative effect of Saussurea lappa and Artemisia absinthium in the chronic hepatitis B. Hence, further studies should be conducted to provide the comparative efficacy with conventional medicine as well as elaborating the mechanism of action in hepatitis B virus induced cirrhosis of liver.

\section{ACKNOWLEDGEMENT}

We are sincerely thankful to all the study participants and pathology department of School of Unani medical education and research, Jamia Hamdard, New Delhi.

\section{CONFLICT OF INTEREST}

The authors declare no conflict of interest.

\section{ABBREVIATIONS}

CHB: Chronic hepatitis B; ALT: Alanine aminotransferase; AST: Aspartate aminotransferase; HBsAg: Hepatitis B surface antigen; HBeAg: Hepatitis B e antigen; SD: Standard deviation; SEM: Standard error of mean; IFN: Interferon;TNF: Tumor necrosis factor; IL: Interleukin.

\section{REFERENCES}

1. Lok AS, Mc Mahon BJ, Brown RS, Wong JB, Ahmed TA, Farah W. Antiviral therapy for chronic hepatitis $B$ viral infections in adults: A systematic review and metanalysis. Hepatology. 2016;63(1):1-13.

2. Anand AC, Pankaj P. Indian Guidelines and Protocols: Hepatitis B [Document on the internet]. 2012. [cited 2014 Feb 3]. Available from: http://www.apiindia.org/ medicine_update_2013/chap53.pdf.

3. World health organisation (WHO). Hepatitis B: In section Global Alert and Response (GAR) [Document on internet]. 2014. [Cited 2014 Jan 7]. Available from: http://www.who.int/mediacentre/factsheets.fs204/en/print.html. 
4. Ibne Sina A, Fit-Tibb AQ. In: Kantoori GH, translator. New Delhi: Aijaz Publishing. 2010;3(1):854-854-859-862, 869-78.

5. Khan H, Azam I. In: H Kabiruddin, translators. New Delhi: Aijaz Publishing 2010;489:505-15.

6. Bae SH, Baek YH, Lee SW, Han SY. Treatment Efficacy of Clevudine, Entecavir and Lamivudine in Treatment-naive Patients with HBeAg-Positive Chronic Hepatitis B. Korean J Gastroenterol. 2010;56(6):365-72.

7. Yaeesh S, Jamal Q, Shah AJ, Gilani AH. Antihepatotoxic activity of Saussurea lappa extract on D-galctosamine and lipopolysaccharide induced hepatitis in mice. Phytother Res. 2010;24(2):S229-32.

8. Cho JY, Baik KU, Jung JH, Park MH. In-vitro anti-inflammatory effects of cynaropicrin, a sesquiterpene lactone, from Saussurea lappa. Eur J Pharmacol. 2000;398(3):399-407.

9. Matsuda H, Toguchida I, Ninomiya K, Kageura T, Morikawa T, Yashikawa M. Effects of serquiterpene and amino acid-serquiterpene conjugates form the roots of Saussurea lappa on inducible nitric oxide synthase and heat shock protein in lipopolysaccharide-activated macrophages. Bioorganic Med Chem. 2003;11(5):709-15.

10. Cho JY, Park J, Yoo ES, Baik KU, Jung JH, Lee J, et al. Inhibitory effect of sesquiterpene lactones from Saussurea lappa on tumor necrosis factor-alpha production in murine macrophage like cells. Planta Med. 1998;64(7):594-597.

11. Jin M, Lee HJ, Ryu JH, Chung KS. Inhibition of LPS-induced NO Production and NF-kappa B activation by a serquiterpene from Saussurea lappa. Arch Pharm Res. 2000;23(1):54-8.

12. Damre AA, Damre AS, Saraf MN. Evaluation of sesquiterpene lactone fraction of Saussurea lappa on transudative, exudative and proliferative of inflammation. Phytother Res. 2003;17(7):722-5.

13. Gokhale AB, Damre AS, Kulkarni KR, Saraf MN. Preliminary evaluation of antiinflammatory and anti-arthritic activity of $S$. lappa, A speciosa and A asoara Phymed. 2002;9(5):433-7.

14. Kang JS, Yoon YD, Lee KH, Park SK, Kim HM. Costunolide inhibits interleukin-1 expression by down-regulation of AP-1 and MAPK activity in LPS-stimulated RAW 264.7 cells. Biochem Biophys Res Commun. 2004;313(1):171-7.
15. Anonymous. The Unani Pharmacopea of India: Qust New Delhi: Central council for research in Unani medicine. 2007;1(1):74-6.

16. Saxena M, Shukla S. Reveral of carbon tetrachloride-induced hep injury by AEE in sprague dawley rats. J Envion Pathol Toxicol Oncol. 2012;31(4):325-34.

17. Amat N, Upur H, Blazekovic B. In-vivo hepatoprotective activity of the AAEE against chemically and immunologically induced liver injuries in mice. J Ethnopharmacol. 2010;130(2):478-84.

18. Blagojevic P, Radulovic N, Palic R, Stojanovic G. Chemical composition of the essential oils of Serbian wild-growing Artemisia absinthium and Artemisia vulgaris. J Agric Food Chem. 2006;54(13):4780-89.

19. Gilani A, Janbaz K. Preventive and curative effects of Artemisia absinthium on acetaminophen and $\mathrm{CCl} 4$ induced hepatotoxicity. Gen Pharmacol. 1995; 26(2):309-15.

20. Kharoubia O, Slimania M, Kroufb D, Seddika L, Aoues A. Role Of Wormwood (Artemisia absinthium) Extract On Oxidative Stress In Ameliorating Lead Induced Haematotoxicity. Afr J Trad CAM. 2008;5(3):263-70.

21. Ahmoudi M, Ebrahimzadeh MA, Ansaroudi F, Nabavi SF and Nabavi SM. Antidepressant and antioxidant activities of Artemisia absinthium L. at flowering stage. Afr J Biotechnol. 2009;8(24):7170-5.

22. Anonymous. The Unani Pharmacopea of India: Afsateen. New Delhi: Central council for research in Unani Medicine. 2007;1(2):3-4.

23. Schiff ER, Sorrell MF, Maddrey WC. Viral hepatitis. Schiff's Diseases of the Liver. 10th ed. Philadelphia: Lippincott Williams and Wilkins. 2007;1:712-13.

24. Pandey RS. Saussurea lappa extract modulates cell mediated and humoral immune response in mice. Der Pharmacia Lettre. 2012;4(6):1868-73.

Article History: Submission Date : 07-03-2018; Revised Date : 09-04-2018; Acceptance Date : 08-06-2018.

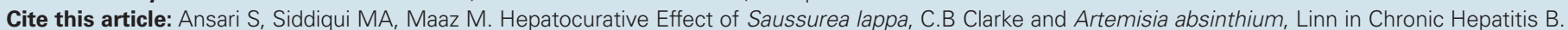
J Young Pharm. 2018;10(3):354-7. 